often throws up clustering bunches of canes that reach a height of sixteen feet in one season. Associated with Arundo conspicua and Gynecium argentum, the above interesting and handsome plants give quite a tropical aspect to some of the hill-sides of this northern county.

Belvoir, December 20

\section{The Appulse of Jupiter to a Fixed Star on November 20}

REFERRING to a request appearing in NATURE, vol. xxiii. p. 158 , I may say that the approach of Jupiter to B.D. +2.97 was well observed here, and $I$ found that the star, when perpendicular to the belts, was $4^{\prime \prime} \cdot 05$ distant from the northern limb. The definition was good, and the measure, I should say, pretty exact.

It was a strange and beautiful sight, Jupiter appearing with five satellites, though, at the same time, the different aspect of the star compared with that of the moons was very striking. The light of the former was however very sensibly affected by the glow of the great disk near it, and it looked no more than ro magnitude.

Millbrook, Taam

\section{British Earthquakes}

MAY I ask leave to offer a few remarks on the leading article on British Earthquales which appeared in NATURE, vol. xxiii. p. II 7. The author brings out very strongly the apparent connection between great lines of jointing or faulting and earthquake movements, and points out the great fault which traverses Scotland from sea to sea as a case in point. Now I had this same question before the British Association this year, and exhibited a map illustrative thereof. I had further, following up a theory submitted by me to the Royal Irish Academy, on the Correlation of Coast-Line Directions, and published by that body, drawn up on a Geikie's Geological Map of Scotland certain of those correlated lines, and on a smaller map of the British Isles had indicated both the lines in question and the localities wherein earthquakes have been noticed in later times, more essentially since 1860. One of those lines crosses the district about Comrie, and at the moment (August, I880) could hardly be pointed out as in any notable way supporting the connection sought to be established between coast-line directions and earthquake localities. But the recent earthquakes in the north of Ireland and in Scotland go far to do this, as the direction shown by me both agrees with the great fault mentioned by the author of the paper on British Earthqualies in direction, and also fairly shows the direction of the earthquake band or zone, which apparently extends from Londonderry across Scotland. This direction is exactly at $40^{\circ}$ with the coust-line direction between Carnsore Point and Wicklow Head, as shown on the accompanying map.

I may add that having had occasion to examine Prof. Höfer's memoir on the "Erdbeben Kärntens und deren Stosilinien," and to compare his lines with those given on the map of Europe exhibited by me at the British Association meeting of this year, I find some very remarkable concordances as regards directions, which, having submitted to him, he quite recognised. I consider therefore that this memoir, Prof. Geikie's very remarkable article on the Volcanoes of North-Western Europe, and this late article on British Earthquakes, all point more and more distinctly to the importance of jointing and fissuring in connection with volcanic and earthquake action, and so far go in support of the theory submitted by me.

Royal College of Sciences, Dublin, December I4

\section{A General Theorem in Kinematics}

I AM very much obliged to Prof. Everett and Mr. J. J. Walker for having taken the trouble to point out that the theorem which I communicated to NATURE is, so far as it relates to uniplanar motion, already known. I am indebted to Prof. Unwin for more complete information on the subject. He tells me that the theorem (for the uniplanar case) has been employed by German engineers in the discussion of stresses produced in moving pieces -exactly the use of the theorem which naturally presents itself. Moreover, the theorem (for the uniplanar case) will be found in $\$ 198$ of Collignon's "Cinématique," as well as in other foreign books, but not, so far as my information goes, in the work of any English author. None of your correspondents or of mine are however able to say that the general case was previously known.
The simple method of proof given by Prof. Everett is that which I had used nearly a month ago in a paper which I wrote (and have since read) for the London Mathematical Society.

I may mention in connection with this subject a kinematical theorem which $\mathrm{Mr}$. Kempe communicated to NATURE some time back. I find that this theorem come; properly under a general theorem which holds for the areas of roulettes. It can be easily proved that the areas of the most general kinds of roulettes follow exactly the law of circular transformation which Steiner proved to hold good for the areas of pedals. For this theorem of Steiner's see Williamson's "Integral Calculus," p. 202, third ed.

Mr. Kempe's theorem (as also Holditch's) is an immediate consequence, since every possible uniplanar displacement of a body can be produced by epicycloidal motion. Mr. Williamson, justly describing Mr. Kempe's as "a singularly elegant theorem" (ibid. p. 210), arrives at it quite differently.

GEORGe M. MinchiN

Royal Engineering College, Cooper's Hill, December $\mathrm{I}_{3}$

\section{A Correction}

In NAture, vol. xxiii. p. 44, Prof. Young has published some experiments proving that the thermo-electric power of a platinum-iron couple is to be observed in vacuo as well as in air ; this fact is said to be contradictory to the results given in my papers. I presume that some error has caused this statement, as I never and nowhere asserted that the thermo-electric power is dependent on the surrounding gases. I have, on the contrary, stated (Phil. Mag., October I88o, p. 294) that no such influence has been hitherto observed. Thus the experiments of Prof. Young do in no way contradict my views.

University of Vienna

Franz EXNER

\section{Jelly Fish}

ON November 3, in the B.I.S.N. Co.'s steamer Arcot, Capt. Stevenson, while in lat. $16^{\circ} 50^{\prime} \mathrm{N}$., long. $55^{\circ} 45^{\prime} \mathrm{E}$., with the Kuriyan-muriyan islands to the north, thirty to forty miles and three days out from Aden to Karachi, we passed through a vast quantity of brown anemones, the ordinary bell-shaped jelly-fish and strange worm.like (apparently) jelly-fisb, floating on and just below the surface. These were first noticed about five in the afternoon, and we were still amongst them when we went below to dinner at six, the vessel steaming about eight knots. The anemones were only peculiar in that they appeared to be rounded at the base and without the ordinary flat surface for adhering to rock or stone; they were in vast numbers and had the feelers expanded. The worm-like or centipede-like jelly-fish were from six to eight feet long and as thick as a man's wrist. They appeared sometimes singly, sometimes many twisted together; they were in slow feeble snake-like motion. All agreed that they were ribbed in appearance; but there was a difference of opinion as to the colour. It was described by some as that of the sea, by others as violet, brown, or purple. Each apparent rib was divided from those next it by a bar of lighter colour.

At night the sea was bright with many phosphoric lights of many shapes, so we were perhaps still passing through the mass. There was a dead calm at the time.

The captain has read this account and stated it to be fairly correct.

Karachi, Sind, November 8

F. C. CONSTABLe

\section{MR. PLIMSOLL'S CURE FOR COLLIERY EXPLOSIONS}

I ET us suppose a person actuated by very powerful motives, who desires to solve the most difficult mathematical problem of the day, and who, after having neglected to acquire the most rudimentary knowledge of his subject, and after having contented himself with seeking the company of land surveyors, and trying to entrap civil engineers into conversations about it, suddenly startles the world with the cry of Eureka! Eureka! Eureka! should we, or should we not, be inclined to regard his solution with respect?

Mr. Plimsoll has done for the mining world exactly what our suppositious person would have accomplished for the mathematical one. In an article contained in the December 
number of the Nineteenth Century, under the title of "Explosions in Collieries and their Cure," he lays before the readers of that magazine an account of the praiseworthy motives which impelled him to seek some means of preventing these horrible disasters; he tells them plainly that he knows little or nothing about the subject, and he recounts what steps he took for the purpose of supplying the want of that knowledge to some extent. He says:-- "In my hope that the resources of chemistry might supply a solution of the problem which has so long perplexed everybody, I have made it my business from time to time to seek the society of practical chemists as well as of purely scientific men whose business it is to teach chemistry. I have seen several amongst the former who are engaged in calico-printing works, lead-works, \&c , and have sought, by getting them to talk about chemistry, and by so to speak lying in wait myself for some hint in their conversation, for something which might supply the missing link."

Mr. Plimsoll then gives an account of how he travelled over the painfully disappointing road of trying to " unmask" the fire-damp, to "make it visible to the eye like smoke or steam," and to indicate its presence by means of a collodion balloon filled with the light carburetted hydrogen and put into a vertical recess glazed in front where it "would float upon the stratum of common air because filled with the lighter gas, but would remain at the bottom of the stratum of gas because kept down by the weight of the envelope inclosing it."

He says of the fire-damp indicator:- "A delicate instrument has been invented, constructed on the principle of the diffusion of gases; but as this would require the application and careful observation of anybody using it, and as all it shows can be equally ascertained by watching the elongation of the flame on the safety-lamp, I pass it by."

He next asks, "Can this gas be absorbed ?" and gives an example of what he means by describing the strong affinity which quicklime has "for hydrogen in the form of water"; and lastly, he puts the question: "Supposing all these branches of inquiry to result unsatisfactorily, whether this gas should be loaded or neutralised in some manner that should render it non-explosive?"

We will pass over the incentives which our author brings forward with the view of stimulating men of science to undertake the work of discovery. That these incentives are strong enough in all conscience we who heard the dreadful sound of the explosion at the Naval Steam-Coal (Penygraig) Collieries as we lay awake shortly after midnight on Friday last can testify from experience. A few hours later we breathed the fatal after-damp in a sufficiently diluted form to produce only headache and nausea: we looked upon the blackened remains of the victims as they lay or knelt on the ground, some having been hurled from a distance and having nearly every bone in their bodies broken, others having their coats tightly drawn over their necks and mouths and their faces buried in the dust, and still others actually kneeling, having their knees drawn more or less closely up under them, their hands pressed on their mouths and their faces also in the dust. We saw nine fine horses that had been struck down where they stood in their stable never to rise again; one that had started off at a mad gallop, and been arrested in six yards by a fall of roof due to the blast which startled him, his legs and his whole body in an attitude of fierce action resting on the top of the fall, and his head laid gently on one side; two others lying on their backs with their legs in the air; another that had turned round in his shafts by some extraordinary convulsion, so that he faced the load he was drawing, while his body, with head erect, was twisted in between two props at the side of the road; and, lastly, a little donkey denuded of harness and tossed like a rag on to a heap of rubbish. We saw many of the bodies carried to the bottom of the shaft and sent to the surface, and others being carried from the pit to the homes where they lately dwelt; we heard the weeping of the bereaved ones; we saw one little knot of mourners from our very window, and since we began to write, as they gathered at the end of a row of houses, were joined by others bearing a coffin on their shoulders, and proceeded slowly down the road and out of sight, while the plaintive Welsh hymn that never fails to accompany such a procession rose and fell on the ear, and died away fitfully amongst the hills.

If any one can see and hear all this and more and remain unmoved, his natural affection is dead, and $\mathrm{Mr}$. Plimsoll's appeal will be made to him in vain. Happily there are many whose hearts are wrung when they see or hear of the sufferings of their fellow-men, and who are always ready and willing to respond to such a cry.

We will now turn to the second part of Mr. Plimsoll's article, where we find his account of the manner in which he proposes to prevent "half, or it may happily prove even more than half, the number of explosions." He describes it in the following words:- "I do not propose to alter anything in existing arrangements in the suggestion I am about to offer, but only to supplement them. Let the present system of ventilation remain as it is in all its vigour, but in regard to the gas which escapes it, gets behind it, and accumulates in the upper and the waste portions of the pit, can we not go arm in arm with Nature in this matter, as we do in the others, and follow the gas whithersoever it goes and thus, in Lord Bacon's words, by obeying Nature learn how to conquer her?

"It goes to the highest part of the pit, therefore into the exhausted spaces. I would work with this tendency, and, as in the case of water, a large hole is dug called a 'sump,' to collect the water at the bottom of the pit and so facilitate its removal by the pumps, so I would make a hole or sump for the accommodation of the gas; but as the water is heavy and lies upon the floor, and has the sump for it made in the floor, so my hole or 'sump' to gather the gas should be in the roof of the mine, and that in the highest accessible places.

"If it were certain that the water will run into the hole or sump dug for it in the floor or the lowest part of the pit, then it is equally certain that the light carburetted hydrogen would rise in the 'sump' or hole dug for it in the highest part of the workings of the pit.

"I would then place a vertical tube with an open trum. pet-shaped mouth, something like the funnel or chimney of a locomotive, in this place, and of such a length that the open mouth (which should be protected with a louvre covering or cap to keep out the dirt) should reach up very near to the roof; the bottom end of this pipe or tube I would continue to the bank of the pit; and as in the case of water you proceed to remove the accumulation by $a$ water-pump, so in this case I would pump out the accumulation of light carburetted hydrogen by means of an air-pump ; probably a small fan like that used in foundries would do as well, or even better.

"This air-pump or fan could easily be worked by a strap from the winding-engine, or by hand. It would require assistance during the daily drawing out of the pipe the atmospheric air which would fill it when the gas was exhausted from the mine. I ask your common sense, could you not as certainly in this way draw off every cubic foot of gas in the mine as you now can certainly remove the water from it?"

Mr. Plimsoll summarises in the following manner :-

"I. Is it not a fact that the light carburetted hydrogen does and will seek the highest place of refuge open to it in the pit? 2. Is it not a fact that at this moment there is scarcely a coal-mine which has not gas in its goaves and highest parts? And 3. Is it not clear that by thus tapping the highest places it can as surely be drawn off as water can be pumped out of a pit?" 
It would be impossible to controvert all the statements that Mr. Plimsoll makes regarding the properties of fire-damp its tendency to rise to the highest point, and so on; he has supplied himself with all the knowledge necessary to understand its behaviour when it is found in easily manageable quantities. But what are we to think of his proposal when we come to deal with such quantities as 1000 and 2000 cubic feet per minute? Two hours after the explosion at the Naval Steam-Coal (Penygraig) Colliery we estimated the amount of fire-damp coming up the upcast at I roo cubic feet per minute, and this is doubtless the normal quantity when the colliery is at work. Dinas Colliery, which adjoins the last-named one, always produced about 1000 cubic feet per minute for some years before the explosion on January I3, I879; Llwynypia Colliery, which adjoins the Naval Steam-Coal Colliery on the other side, produced 2000 cubic feet per minute for some years, but its output of coal is now less, and consequently its production of gas has decreased.

But where does this gas come from, and how is it disposed of? In following one of the subdivisions of the air-current from the point where it leaves the main intake air-current to the point where it returns to the main return air-current we observe the following phenomena. On reaching the first working place the air is still apparently as pure as it was when it left the surface; about the fifth or sixth place it begins to show the first symptoms of gas on the small flame of a glass safety-lamp (it is still invisible in a Davy lamp); at the tenth place the cap is quite apparent even to the unpractised eye; at the fifteenth place it is say $\frac{3}{16}$ of an inch in height, and at the twentieth place it is a $\frac{1}{4}$ of an inch. This is enough, and the current returns towards the upcast shaft without passing through any more places. At the point of its junction with the main return air-current its cap remains exactly the same as it was when it left the last face. We have ourselves verified these observations hundreds of times in different mines. The number of places through which the air must pass in order to obtain a given proportion of gas varies according to the rate at which gas is produced in the mine in question, and the volume of air passing along the faces.

In the most fiery mines we can generally follow the air-current from the surface, and return with it again to the surface after having passed along the working places without having seen the least accumulation of explosive gas. This is the rule; a cavity left by a fall of roof and containing explosive gas is the exception, and not only is no work allowed to be carried on near it, but means are taken to ventilate it as quickly as possible.

How then could Mr. Plimsoll's method be applied under these circumstances? Should we slacken the ventilation in order to give the gas time to rise to the roof, and after it got there to give it a chance of finding its way to a sump excavated for it somewhere or other? If so we should have streams of explosive gas travelling along the roof of the working places, and our dangers would be increased a thousandfold. We do not know what kind of mines those are in which Mr. Plimsoll has seen a stratum of explosive gas along the roof of the airways, but we should prefer not to have anything to do with them, even were his method applied for the purpose of drawing off the gas.

Let us take the explosion that has just occurred in the Rhondda Valley as an example. About ten months ago the two shafts, which are about IIII yards apart, and over 400 yards deep, were connected together by an approximately straight heading, which is driven nearly level in coal from each shaft for say 520 yards, and descends the slope of a fault for 60 yards. The coal in one shaft is 30 yards below the level of that in the other shaft, and the surface of the ground at the top of the former shaft is 188 feet higher than at the latter. The fault forms a natural boundary between the workings of the two shafts, and, except for purposes of ventilation and communication, they were treated as distinct collieries. The workings are ranged on each side of the straight heading, there being four districts at the lower level (three on the right hand and one on the left, looking towards the higher shaft), and one district at the higher level (on the right hand side, looking in the same direction). The natural direction of the air-current is from the lower to the higher shaft. The natural air-current gives a volume of about 30,000 cubic feet of air per minute at the present moment, and we are informed that when the fan was at work the volume was between 60 and 80,000 cubic feet. The envelope of the fan was destroyed by the explosion, and the natural ventilation had to be depended on for the explorations so far as they have been carried.

Soon after midnight on the morning of Friday last there were somewhat over one hundred men and boys busily employed underground: five were at the bottom of the upper shaft, four at the bottom of the lower shaft ; seventeen or so were on the straight heading about half-way between the fault and the upper shaft; twenty-four were in the left-hand workings of the lower shaft ; several gangs of from three to six were in each of the other three small districts of the lower workings ; fifteen or so were in the right-hand workings constituting the only district in the upper pit; some were cutting coal, others were blasting down roof, some were filling rubbish, others were stowing it into empty places, and here and there a horse and his driver were proceeding along the roadways with short trains of full or empty waggons.

No explosive accumulation of gas is said to have been found in the mine when it was examined a few hours previously, and two men, who came up only a few minutes before the explosion, had not heard of any unusual occurrence. The mine is a very dry one, and there is abundance of very fine coal-dust to be found everywhere on the roadways.

A sudden shock was felt; a veritable hurricane swept through every passage and every open space communicating with the air-ways; a "darkness that might be felt" ensued for an instant, then a gleam of brilliant light accompanied by a shower of molten and red-hot dust, then darkness again, and all was still.

During the interval between the raising of the dust and the passage of the flame some of the men, who evidently knew what had occurred, pulled their coats over their necks and mouths and staggered outwards, but fell after they had gone at most six or eight yards; others, as we have said, knelt down, covered their faces with their hands, and buried their mouths in the dust and small coal on the floor; the terrified horses made a few mad plunges, and then the Angel of Death breathed upon them all, and they remained transfixed in the positions they had assumed at that fatal moment. Only five men who were engaged in workings close to the downcast shaft escaped alive. They were rendered insensible by the after-damp, but recovered consciousness before the exploring parties reached them, having been revived by the fresh air which immediately flowed into the downcast shaft after the explosion was over.

We ask now where was the fire-damp accumulated that could produce so widespread an explosion, and at what part of the colliery would Mr. Plimsoll have placed his apparatus for the purpose of pumping it out?

The flame ramified into every district of workings both in the upper and lower pit, and left unmistakable tokens of its presence in the form of crusts of coked coal-dust on the timber, on the coal, and on some of the men's bodies.

It is evident that Mr. Plimsoll has remained unnecessarily ignorant that many men have been engaged in working out the problem he has attempted to solve. Let him go back to the many volumes of Parliamentary evi- 
dence for information that will enable him to avoid all his useless work in trying to find means of " unmasking" or absorbing the gas; let him take up Faraday and Lyell's report on the Haswell Colliery explosion of 1844 , and he will find his own proposal described in every essential detail, as well as a hint thrown out that coal-dust has much to do with explosions; let him peruse the copy of the report addressed to the United Committee of the Coal Trade by the Special Committee appointed to take into consideration Faraday and Lyell's report, and he will find the opinion expressed by the practical men of that day regarding the very plan he now brings forward as original.

But why should he labour through all that mass of reading and more than we have named, when he can find all that is of any value on the subject condensed in that most admirable dissertation, entitled "Rapport de $M$. Haton de la Goupillière (Ingenieur-en-chef des Mines, Professeur d'Exploitation des Mines al l'École des Mines), au nom de la Commission d'Étude des Moyens propre a prévenir les Explosions du grisou " (Paris: Dunod, Editeur, Quai des Augustins, No. 49, 1880). In that volume he will find an account of all his own plans and those of many others, as well as much valuable information that will prove of inestimable value to him if he should decide to pursue this subject to its legitimate ccnclusion, as we most earnestly hope he will.

Mr. Plimsoll wrongs the scientific and mining sections of the community when he charges them with so much indifference. In England, in France, and in Belgium there is at present a Government Commission considering the subject of his article, viz. "Explosions in Collieries and their Cure," and collecting evidence which will be of great value in enabling us to approach nearer to the mark we are all aiming at.

As usual the Royal Society travels in the van, and to our certain knowledge has given the sum of no less than $255 l$. within the last seven or eight years towards assisting in experiments which are being made with the view of throwing light upon the subject.

Similarly each of the Mining Institutes is eagerly canvassing every scrap of useful knowledge that may tend to lessen the risks of mining, and especially of explosions.

Lastly, in Germany we have also activity; and we can recommend a perusal of a pamphlet entitled "Die Verhüttung von Explosionen schlagender Wetter in Steinkohlenbergwerken," by Dr. Adolf Gurlt, Bergingenieur, Bonn: Verlag von Max Cohen und Sohn (Fr. Cohen), 1880. This pamphlet ends with the following words, in which it appeals to thoughtful miners. We would extend the same appeal to one and all :-

"So mögen denn alle denkenden Bergmänner ihre Kräfte vereinigen um dem verderblichen Feinde des Kohlenbergmannes, dem Grubengase, diesem Moloch, welcher noch fortwährend so viele frische Menschenleben verschlingt, in Zukunft seine Opfer nach Möglichkeit zu entreissen."

If really safe safety-lamps were introduced that could not under any circumstances ignite an explosive mixture of fire-damp and air; and if at the same time the use of an explosive or other agent that produced no flame were substituted for that of gunpowder or dynamite, we might be comparatively free from explosions.

Thus far however neither the one nor the other of these desirable consummations has been attained.

On the other hand, if we could entirely eliminate explosive accumulations of fire-damp and air from our mines we should expect, according to the most generally received opinions, to be able to use naked lights and to fire shots wherever we had a mind to do so. Naked lights we might use under these circumstances; but we should protest in the strongest terms against blasting in the presence of dry coal-dust alone. The rôle of that agent has not yet been officially recognised, at least to the extent of framing special regulations to assist in dealing with it; and until it is so recognised we venture to assert that explosions will continue, and that the same impossibility of explaining them, save by the assumption of simultaneous eruptions of fire-damp in different parts of the workings, will continue to be experienced.

That this is an illogical method of accounting for them may be gathered from the fact that the Risca explosion of July last required no less than three simultaneous eruptions to explain it. The Penygraig explosion would require one in each district; but we say this without prejudice to the evidence either direct or circumstantial that may yet be forthcoming to prove the existence of explosive accumulations in one or more places in the workings.

In conclusion we would say that the Penygraig explosion cannot be explained by the fire-damp hypothesis alone; explosive accumulations may have been accidentally ignited by a shot, or by a defective safety-lamp, and so have originated the explosion; but something else than fire-damp, something whose presence was entirely ignored, took up the flame, carried it to the innermost and to the most extreme limits of the workings, and was in all probability the cause of 90 per cent. or more of the deaths that ensued. Need we state our absolute conviction that that obscure agent was coal-dust?

\section{W. Galloway}

\section{COL. PRSHEVALSKYS' RECENT JOURNEY}

THE new number of the Izvestia of the Russian Geo. graphical Society contains the long-expected letters from Col. Prshevalsky on his adventurous journey on the frontier of Tibet. We have already referred to Col. Prshevalsky's work ; the following further details will be of interest:- His last news were dated from Hami, whence he proposed to go south-east to Tsaïdam. But it was impossible to find a guide : a Chinese, given for this purpose by the Hami authorities, left the expedition some fifty miles from the town, after having led the travellers into a region full of great ravines. M. Prshevalsky, confident in his eleven companions, resolved to find his way himself by sending every day two men on horseback: for distances of thirty and fifty miles round to discover the best direction. The advance was very slow, and the travellers spent one month and a half in the mountains south of Sa-djeou, discovering the high mountain-ranges to which they gave the names of Humboldt and Ritter. After a march of 190 miles they arrived at Kourlyk in the Tsaïdam, but here also they were badly received, and could not find guides, owing to the secret influence of the Chinese. Finally M. Prshevalsky told the chief of Kourlyk that he would take him as guide to Tibet if another guide could not be found, and on the following day the guide was found.

On September 24 the travellers left Tsaïdam. Again the guide led them into impracticable tracts near to the Blue River, so that M. Prshevalsky's expedition was compelled again to seek its own way. After having crossed the Blue River at its sources, they climbed the high plateau of Tan-la, after having crossed the 16,800 feet high pass across the border-range, which was covered with snow in October. On the passage they were attacked by the nomad tribe of Egrays, but the companions of M. Prshevalsky gave them a hot reception, and the Egrays fled, leaving four killed and several wounded.

Descending from the Tan-la ridge, the expedition continued its way to Lassa, but at the Nabchou settlement, 160 miles distant from the capital of the Dalaï-Lama, they were met by Tibetians, who declared that the expedition could not be allowed to go further without a permission from the Lassa authorities; a thousand soldiers were assembled at Nabchou. M. Prshevalsky gave his consent to await an answer from Lassa, and stayed at 